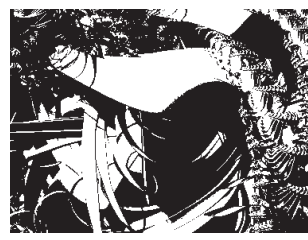

\title{
POVEZANOST PRIVRŽENOSTI RODITELJIMA S RIZIČNIM I DELINKVENTNIM PONAŠANJEM KOD ADOLESCENATA
}

Silviija RUČEVIĆ

Filozofski fakultet, Osijek

UDK: 159.942.52-053.6:316.624

Izvorni znanstveni rad

Primlieno: 24. 4. 2009.

Ovo istraživanje je provedeno u sklopu projekta "Djeca, mladi, obitelii i socijalni razvoi Hrvatske" (066-0661686-1431), što ga financira Ministarstvo znanosti, obrazovanja i športa.

Osnovni cili ovoga rada bio je ispitati povezanost privrženosti mjerene na nekoliko dimenzija (komunikacija, povjerenje i otuđenost) i raznih oblika delinkventnoga i rizičnoga ponašanja na mladićima $(n=226)$ i djevojkama $(n=480)$ iz opće populacije od 13 do 19 godina. Konkretno, istraživanje je ispitivalo (a) ulogu spola kao moderatora efekata dimenzija privrženosti na izraženost pojedinih oblika rizičnoga i delinkventnoga ponašanja kao i (b) učinke jednog od roditelja i obaju roditelja kojima je osoba visoko privržena na izraženost raznih oblika rizičnoga $i$ delinkventnoga ponašanja. Delinkventno i rizično ponašanje, kao i privrženost, mjereni su samoiskazom. Rezultati općenito pokazuju efekt spola na odnos između privrženosti ocu i majci te delinkventnoga, ali ne i rizičnoga, ponašanja. Analiza je pokazala da izraženost delinkventnoga ponašanja s povećanjem privrženosti ocu i majci više opada kod mladića nego kod dievojaka. Rezultati također pokazuju da visoka privrženost jednom roditelju podjednako učinkovito inhibira delinkventno ponašanje kao i visoka privrženost dvama roditeljima. Dobiveno je da je visoka privrženost roditelju skrbniku u jednoroditeliskom domu podjednako učinkovita $u$ kontroliranju rizičnoga $i$ delinkventnoga ponašanja kao i visoka privrženost dvama roditelijma u dvoroditeliskim obitelijma.

Ključne riječi: privrženost, delinkventno ponašanje, rizično ponašanje, teorija socijalne kontrole

$\triangle$ Silvija Ručević, Sveučilište J. J. Strossmayera u Osiijeku, Filozofski fakultet, Studii psihologije, L. Jägera 9, 31000 Osiiek, Hrvatska. E-mail: s.rucevic.03@cantab.net 
Dosadašnja istraživanja rizičnoga i delinkventnoga ponašanja pokazuju da su pojava i razvoj delinkventnoga ponašanja povezani s nizom čimbenika rizika, među kojima značajnu ulogu imaju obiteljski čimbenici kao što su neadekvatna roditeljska supervizija, velike i brojne obitelji, niska uključenost roditelja u život djece te sukob među roditeljima (Derzon i Lipsey, 2000.; Farrington, 1997.; Piquero i sur., 2007.; Wasserman i Seracini, 2001.). Međutim, još nije potpuno razjašnjeno koji se mehanizmi nalaze u podlozi te povezanosti. Novija istraživanja sugeriraju da su obiteljski čimbenici rizika i delinkventno ponašanje povezani indirektno raznim aspektima interakcije roditelja i djece, npr. nadzorom i privrženošću (Chen i Kaplan, 1997.; Farrington i Welsh, 2007.; Goetting, 1994.; Van Voorhis i sur., 1988.). Jedna od prvih i danas najutjecajnijih teorija koja je pokušala objasniti ovu indirektnu povezanost kroz privrženost roditeljima jest Hirschijeva teorija socijalne kontrole (1969.).

Teorija socijalne kontrole započinje općom pretpostavkom da je "delinkventno ponašanje posljedica prekida ili slabljenja veza između pojedinca i društva" (Hirschi, 1969., 16). Kao što je navedeno, ova se teorija usredotočuje na povezanost privrženosti roditeljima i delinkventnoga ponašanja, pri čemu se privrženost definira kao afektivni odnosi koje djeca i mladi formiraju s drugim važnim osobama, najčešće roditeljima. Hirschi navodi tri dimenzije afektivnih odnosa, tj. privrženosti: (1) afektiona identifikacija - ljubav i poštovanje koje djeca osjećaju prema roditeljima, (2) intimnost komunikacije - roditeljeva upoznatost s brigama i problemima djeteta i (3) supervizija - "psihološka" prisutnost roditelja kada se javi prilika za delinkventno ponašanje. Ove tri dimenzije određuju kvalitetu privrženosti roditeljima. Ako odnosi s roditeljima oslabe, vjerojatnost javljanja delinkventnoga ponašanja raste, dok se jačanjem ovih odnosa vjerojatnost manifestiranja delinkventnoga ponašanja smanjuje. Hirschi također naglašava da nije važno je li osoba privržena jednom ili dvama roditeljima, odnosno, privrženost dvama roditeljima nema dodatni inhibitorni učinak na delinkventno ponašanje u odnosu na privrženost samo jednom roditelju.

Rezultati brojnih istraživanja pokazuju da je privrženost negativno i umjereno povezana s delinkventnim ponašanjem, tj. da niska privrženost roditeljima povećava vjerojatnost manifestiranja delinkventnoga ponašanja (npr. Cernkovich i Giordano, 1987.; Junger-Tas, 1992.; Mak, 1991.; Rankin i Wells, 1990.; Sampson i Laub, 1994.). Međutim, pokazalo se i to da je vjerojatnost manifestiranja delinkventnoga ponašanja veća kod djece koja su privržena samo jednom roditelju u odnosu na dje- 
DRUŠ. ISTRAŽ. ZAGREB GOD. 20 (2011), BR. 1 (111)

STR. 167-187

RUČEVIĆ, S.: POVEZANOST.. cu koja su privržena i ocu i majci (npr. Rankin i Kern, 1994.). Dakle, moglo bi se postaviti pitanje postoji li ipak dodatni inhibitorni učinak privrženosti dvama roditeljima u odnosu na privrženost samo jednom roditelju?

Dosadašnja istraživanja odnosa privrženosti roditeljima i delinkventnoga ponašanja u okviru teorije socijalne kontrole imaju i brojne nedostatke. Prvo, prethodna istraživanja uglavnom su zanemarivala ulogu spola kao moderatora odnosa privrženosti roditeljima i pojave delinkventnoga ponašanja. Prema teoriji socijalne kontrole, nije važan ni spol djeteta ni spol roditelja kojem je dijete privrženo, nego je visoka kvaliteta privrženosti per se dovoljna za inhibiciju delinkventnoga ponašanja. Međutim, malobrojna istraživanja koja su se bavila ovim problemom daju nekonzistentne rezultate. Dok neka istraživanja, u skladu s teorijom socijalne kontrole, ne nalaze značajan interakcijski efekt spola i privrženosti roditeljima na delinkventno ponašanje (npr. Nelson i Rubin, 1997.; Rankin i Kern, 1994.; Sokol-Katz i sur., 1997.), u drugima je utvrđena razlika odnosa privrženosti i delinkventnoga ponašanja između mladića i djevojaka. Istraživanje Canter (1982.) nalazi da je inhibitorni učinak privrženosti roditeljima nešto jači kod djevojaka. Suprotno tome, u nekoliko istraživanja pronađeno je da je inhibitorni efekt privrženosti na delinkventno ponašanje jači kod mladića (npr. Anderson i sur., 1999.; Cernkovich i Giordano, 1987.; Cota-Robles i Gamble, 2006.). Dakle, još se malo zna o tome postoje li spolne razlike u efektu privrženosti roditeljima na delinkventno ponašanje.

Drugo, $u$ istraživanjima se najčešće rabi jedinstvena, opća mjera delinkventnoga ponašanja (npr. Anderson i sur., 1999.; Cota-Robles i Gamble, 2006.). Takva mjera obuhvaća ponašanja različite težine i različitih oblika delinkventnoga ponašanja (npr. nasilne oblike ponašanja, krađe, zlouporabu psihoaktivnih tvari itd.). Zato i nije poznato jesu li obrasci povezanosti između različitih oblika i težina delinkventnoga ponašanja i privrženosti roditeljima slični ili različiti, tj. ima li privrženost roditeljima podjednak inhibitorni učinak neovisno o obliku i težini delinkventnoga ponašanja.

Nadalje, većina istraživanja gotovo se ekskluzivno usredotočila na delinkventno ponašanje, tj. na ona ponašanja mladih koja su zabranjena zakonskim propisima, dok istraživanja koja ispituju povezanost privrženosti roditeljima i rizičnih ponašanja, npr. rizično spolno ponašanje, gotovo i nema. $S$ obzirom na to da se $\mathrm{u}$ adolescenciji prevalencija rizičnih ponašanja povećava (npr. Moffitt, 2006.), važno je provjeriti ima li privrženost roditeljima inhibitorni učinak i za ove oblike ponašanja te u kojoj je mjeri on sličan ili se razlikuje od učinka za različite oblike delinkventnoga ponašanja. Ovaj je nedostatak 
DRUŠ. ISTRAŽ. ZAGREB GOD. 20 (2011), BR. 1 (111)

STR. 167-187

RUČEVIĆ, S. POVEZANOST. posebno istaknut kada je riječ o ispitivanjima koja uključuju i djevojke. Naime, prethodna istraživanja pokazala su značajne i konzistentne razlike u manifestaciji delinkventnoga ponašanja između mladića i djevojaka. Dok mladići manifestiraju nasilne oblike delinkventnoga ponašanja, kod djevojaka su češći nenasilni oblici te rizična ponašanja, npr. krađa, prijevara ili prostitucija (Eme i Kavanaugh, 1995.; Leadbeater i sur., 1999.; Moffitt i sur., 2001.). Stoga je moguće da je ovaj konceptualni problem jedan od razloga nekonzistentnih rezultata istraživanja kojima se ispitivala moderatorska uloga spola.

Treće, $u$ većini istraživanja rabila se jedinstvena mjera privrženosti dvama roditeljima (npr. Anderson i sur., 1999.; Gottfredson i sur., 1991.; Rankin i Wells, 1990.). Međutim, na temelju ovakve jedinstvene mjere teško je procijeniti je li osoba, na primjer, visoko privržena samo majci, samo ocu ili je umjereno privržena dvama roditeljima.

Naposljetku, gotovo da i nema integrativnih istraživanja koja bi ispitala koliko su za rizično i delinkventno ponašanje važni obrasci povezanosti između različitih dimenzija privrženosti. Iako još postoji neslaganje između broja dimenzija privrženosti i operacionalizacije privrženosti, istraživanja su pokazala da su bliski odnosi s roditeljima (neovisno o tome kako su operacionalizirani) negativno povezani s delinkventnim ponašanjem. Dakle, ispitivanje dimenzija privrženosti moglo bi pružiti dodatni uvid u povezanost različitih aspekata odnosa s roditeljima i različitih oblika rizičnoga i delinkventnoga ponašanja, kao i važnost pojedinih dimenzija za djevojke i mladiće.

\section{O ovom istraživanju}

Cilj je ovog istraživanja ispitati povezanost privrženosti majci i privrženosti ocu s različitim oblicima rizičnoga i delinkventnoga ponašanja, pri čemu su uz opću privrženost ispitani i obrasci povezanosti za dimenzije privrženosti. Ispitana je i interakcija spola roditelja i djece da bi se provjerilo imaju li očevi i/ili majke veći učinak na rizično i delinkventno ponašanje kćeri i/ili sinova. Provjerena je i hipoteza da je visoka privrženost jednom roditelju podjednako učinkovita u preveniranju delinkventnoga ponašanja kao i visoka privrženost dvama roditeljima. Naposljetku, provjerena je hipoteza da je visoka privrženost roditelju skrbniku u jednoroditeljskom domu (skrbnik majka) podjednako učinkovita u kontroliranju rizičnoga i delinkventnoga ponašanja kao i visoka privrženost dvama roditeljima u dvoroditeljskim obiteljima.

Podaci o rizičnom i delinkventnom ponašanju mladih prikupljeni su samoiskazom. Iako je ponekad u literaturi prisutna skeptičnost kada je riječ o upotrebi samoiskaza u istraži- 
DRUŠ. ISTRAŽ. ZAGREB GOD. 20 (2011), BR. 1 (111)

STR. 167-187

RUČEVIĆ, S.: POVEZANOST..

\section{METODA}

\section{Sudionici}

\section{Upitnici}

vanjima delinkventnoga ponašanja, istraživanja su pokazala da su mladi ne samo voljni priznati već da to čine i u iznenađujuće velikom broju te da su samoiskazi valjane i pouzdane mjere delinkventnoga ponašanja (npr. Farrington i sur., 2000.; Farrington i West, 1990.; Jolliffe i sur., 2003.; Junger-Tas i Marshall, 1999.; Piquero i sur., 2007.; Thornberry, i Krohn, 2000.). $\mathrm{U}$ ovom istraživanju delinkventno ponašanje definirano je kao ponašanje koje je zabranjeno zakonskim propisima i za koje postoje propisane sankcije (Mikšaj-Todorović, 2004.; Šućur, 2004.), dok je rizično ponašanje definirano kao ponašanje koje nije kršenje postojećih pravnih propisa, ali se u dosadašnjim istraživanjima pokazalo kao ponašanje koje prethodi delinkventnom ponašanju ili se često javlja uz delinkventno ponašanje. To su npr. ponašanja poput konzumacije alkohola, bježanja iz škole, rizičnih spolnih ponašanja, autoagresivnih ponašanja itd. U istraživanju se primjenjuje i samoprocjena privrženosti roditeljima, koje su vrlo česte $\mathrm{u}$ istraživanjima privrženosti $u$ adolescenciji i odrasloj dobi. Na temelju samoprocjena privrženosti istraživači dobivaju uvid u kognitivne reprezentacije pojedinčevih unutrašnjih radnih modela (Berlin i Cassidy, 1999.).

Prethodno navedene hipoteze i rezultati istraživanja odnosa između kvalitete privrženosti i rizičnoga i delinkventnoga ponašanja temelje se na Hirschijevoj konceptualizaciji privrženosti.

U ispitivanju je sudjelovalo 706 ispitanika, od čega $226(32,1 \%)$ muškoga i $480(67,9 \%)$ ženskoga spola. Prosječna dob mladića $(\mathrm{M}=15,88 ; \mathrm{SD}=1,87)$ i djevojaka $(\mathrm{M}=15,99 ; \mathrm{SD}=1,61)$ gotovo je ista $(\mathrm{t}(703)=-0,81 ; \mathrm{p}>0,05)$. Sudionici su bili polaznici različitih osječkih škola, i to 7. i 8. razreda osnovne škole te od 1 . do 4. razreda srednje škole (gimnazije i strukovne škole). Raspon dobi sudionika bio je od 13 do 19 godina $(\mathrm{M}=15,95 ; \mathrm{SD}=1,70)$, pri čemu su članovi pojedinih dobnih skupina bili podjednako zastupljeni u ukupnom uzorku. Njih 117 (32 mladića i 85 djevojaka) živi u jednoroditeljskim obiteljima s majkom kao roditeljem skrbnikom.

\section{Rizično i delinkventno ponašanje}

Rizično i delinkventno ponašanje mjereno je Upitnikom samoiskaza rizičnog i delinkventnog ponašanja mladih (SRDP-2007) (Ajduković, Ručević, Šincek, 2009.). Upitnik mjeri frekvenciju raznih oblika rizičnoga i delinkventnoga ponašanja 
DRUŠ. ISTRAŽ. ZAGREB GOD. 20 (2011) BR. 1 (111)

STR. 167-187

RUČEVIĆ, S. POVEZANOST. ikada počinjenih, a sastoji se od 43 čestice zasićene sa sedam faktora, i to (1) Prekršajna i lakša delinkventna ponašanja; (2) Nepoželjna normativna ponašanja; (3) Rizična spolna ponašanja; (4) Korištenje ili zlouporaba psihoaktivnih tvari; (5) Nasilničko ponašanje u bliskim odnosima; (6) Teške krađe, provale i razbojništvo; (7) Suicidalna i autoagresivna ponašanja. Od navedenih faktora tri se odnose na rizična ponašanja (faktori 2, 3 i 7), a preostali na delinkventno ponašanje. Ukupna mjera delinkventnoga ponašanja (SRDP ukupno) dobivena je zbrajanjem odgovora na česticama. Pouzdanost unutarnje konzistencije (Cronbach-alpha) dobivenih faktora rizičnoga i delinkventnoga ponašanja kreće se od 0,53 za suicidalna i autoagresivna ponašanja do 0,81 za prekršajna i lakša delinkventna ponašanja. Korelacije između pojedinih faktora kreću se $u$ rasponu od $\mathrm{r}=0,14(\mathrm{p}<0,001)$ do $0,50(\mathrm{p}<0,001)$.

\section{Privrženost}

Za mjerenje kvalitete i dimenzija privrženosti uzet je Inventar privrženosti roditeljima i vršnjacima (IPPA; Inventory of parent and peer attachment) (Armsden i Greenberg, 1987.). Teorijska konceptualizacija privrženosti kojom se služe autori ovog upitnika slična je Hirschijevoj (1969.) te je privrženost definirana kao kognitivni i emocionalni aspekti odnosa s roditeljima. Nadalje, čestice u ovom upitniku sadržajno su vrlo slične onima koje je Hirschi rabio u svojem istraživanju, što olakšava integraciju i usporedbu rezultata ovih istraživanja.

Upitnik mjeri kvalitetu privrženosti, a sastoji se od 25 čestica (za svakoga roditelja) koje su zasićene trima faktorima: (1) Povjerenje mjeri stupanj međusobnoga razumijevanja i poštovanja u odnosu privrženosti, (2) Komunikacija daje procjenu dubine i kvalitete verbalne komunikacije te (3) Otudenost mjeri osjećaje ljutnje i interpersonalne otuđenosti. Za svaku tvrdnju odgovara se na skali Likertova tipa od pet stupnjeva od "1 - gotovo nikad" do "5 - uvijek točno ili gotovo uvijek točno", pri čemu niži rezultat označuje nižu kvalitetu privrženosti. U ovom istraživanju uzete su samo čestice kojima se mjeri privrženost majci i privrženost ocu.

Kako bismo provjerili strukturu hrvatske verzije ovog $\mathrm{u}$ pitnika, provedena je konfirmatorna faktorska analiza. S obzirom na to da ovaj inventar sadrži zasebne čestice kojima se mjeri privrženost ocu i privrženost majci, provedene su konfirmatorne faktorske analize zasebno za majku i oca. Testirajući originalnu trofaktorsku strukturu Inventara privrženosti roditeljima, dobiveni su zadovoljavajući indeksi pogodnosti, koji su prikazani u Tablici 1 . Hi-kvadrat je statistički značajan, međutim, ovaj je indeks vrlo osjetljiv na veličinu uzorka. Odnosno, kod velikih uzoraka (većih od 200) rijetko je neznačajan te se $\mathrm{u}$ takvim slučajevima rabe druge mjere pogodnosti 
DRUŠ. ISTRAŽ. ZAGREB GOD. 20 (2011), BR. 1 (111)

STR. 167-187

RUČEVIĆ, S.:

POVEZANOST..

- TABLICA 1

Indeksi pogodnosti za trofaktorsko riešenje za privrženosł majci i privrženost ocu

(1) TABLICA 2

Korelacije između dimenzija Inventara privrženosti roditelijima modela (Hu i Bentler, 1999.). Indeksi koji govore o ukupnoj količini objašnjene varijance modela nešto su ispod ili na granici prihvatljivosti, dok su indeksi koji govore o rezidualnom varijabilitetu i razlici između strukture kovarijanci populacije i one predviđene modelom prihvatljivi. Indeksi pogodnosti nešto su bolji za trofaktorsku strukturu privrženosti majci nego privrženosti ocu.

\begin{tabular}{lrrr}
\hline $\begin{array}{l}\text { Indeksi } \\
\text { pogodnosti }\end{array}$ & $\begin{array}{r}\text { Privrženost } \\
\text { majci }\end{array}$ & $\begin{array}{r}\text { Privrženost } \\
\text { ocu }\end{array}$ & $\begin{array}{r}\text { Referentne } \\
\text { vrijednosti }\end{array}$ \\
\hline$\chi^{2}$, ss; $p$ & $\begin{array}{rrr}963,31,272 ; \\
p<0,001\end{array}$ & $\begin{array}{r}1108,49,272 ; \\
p<0,001\end{array}$ & $\begin{array}{r}\text { Neznačajan } \\
\text { hi-kvadrat }\end{array}$ \\
CFI & 0,87 & 0,87 & $\geq 0,90$ \\
GFI & 0,85 & 0,82 & $\geq 0,85$ \\
AGFI & 0,82 & 0,79 & $\geq 0,80$ \\
RMSEA & 0,059 & 0,066 & $\leq 0,08$ \\
RMR & 0,063 & 0,071 & $\leq 0,10$ \\
\hline
\end{tabular}

$\mathrm{SS}=$ stupnjevi slobode

Pouzdanosti unutarnje konzistencije (Cronbach-alpha) dobivenih dimenzija privrženosti iznose 0,89 za Povjerenje-majka i 0,88 za Povjerenje-otac; 0,91 za Komunikaciju-majka i 0,88 za Komunikaciju-otac te 0,68 za Otuđenost-majka i 0,68 za Otuđenost-otac. Naposljetku, Opća privrženost dobivena je zbrajanjem svih odgovora $(\alpha=0,79$ za majku i $\alpha=0,79$ za oca). Korelacije među pojedinim dimenzijama privrženosti majci i ocu prikazane su u Tablici 2.

\begin{tabular}{lccccccc}
\hline Dimenzije & KomM & OtuđM & OpćaM & PovO & KomO & OtuđO & OpćaO \\
\hline Povjerenje-majka (PovM) & $0,77^{* *}$ & $-0,62^{* *}$ & $0,90^{* *}$ & $0,35^{* *}$ & $0,38^{* *}$ & $-0,24^{* *}$ & $0,38^{* *}$ \\
Komunikacija-majka (KomM) & & $-0,61^{* *}$ & $0,91^{* *}$ & $0,28^{* *}$ & $0,41^{* *}$ & $-0,22^{* *}$ & $0,36^{* *}$ \\
Otuđenost-majka (OtuđM) & & & $-0,42^{* *}$ & $-0,28^{* *}$ & $-0,36^{* *}$ & $0,42^{* *}$ & $-0,25^{* *}$ \\
Opća-majka (OpćaM) & & & & $0,29^{* *}$ & $0,37^{* *}$ & $-0,14^{*}$ & $0,38^{* *}$ \\
Povjerenje-otac (PovO) & & & & & $0,80^{* *}$ & $-0,67^{* *}$ & $0,89^{* *}$ \\
Komunikacija-otac (KomO) & & & & & & $-0,64^{* *}$ & $0,92^{* *}$ \\
Otuđenost-otac (OtuđO) & & & & & & & $-0,45^{* *}$ \\
Opća O-Opća privrženost ocu & & & & & & & \\
\hline
\end{tabular}

${ }^{* *} \mathrm{p}<0,001 ;{ }^{* *} \mathrm{p}<0,01 ;{ }^{*} \mathrm{p}<0,05$

\section{Postupak}

Upotrijebljeni uzorak izvučen je iz populacije adolescenata tako da je uzorak ispitanih škola bio prigodan, pri čemu su obuhvaćene škole iz centra grada, kao i škole u koje idu djeca i mladi iz prigradskih naselja. Odabrane su i gimnazije i strukovne škole raznih usmjerenja i dužine trajanja (trogodišnje i četverogodišnje). Razredi koji su unutar pojedinih škola su- 
djelovali u ispitivanju izabrani su slučajno. Ispitivanje se provodilo grupno u trajanju od jednoga školskog sata.

\section{REZULTATI}

(1) TABLICA 3

Usporedba rezultata mladića i dievojaka na Upitniku SRDP-a
Slično prethodnim istraživanjima, npr. Cota-Robles i Gamble (2006.), dobivene su značajne razlike između mladića i djevojaka samo na mjerama koje se odnose na kvalitetu privrženosti majci, pri čemu su djevojke na dimenzijama Povjerenje $(t(569)=-3,67, p<0,01)$, Komunikacija $(t(577)=-7,90, p<0,001)$ te Općoj privrženosti $(\mathrm{t}(560)=-5,78, \mathrm{p}<0,01)$ postizale značajno viši rezultat od mladića, a na dimenziji Otuđenost $(\mathrm{t}(577)=4,41, \mathrm{p}<0,01)$ značajno niži. Nisu dobivene značajne razlike između dimenzija privrženosti majci i dimenzija privrženosti ocu, kao ni za opću privrženost. Nije dobivena ni razlika s obzirom na procjenu privrženosti majci sudionika iz dvoroditeljskih i jednoroditeljskih obitelji. Nadalje, korelacije između svih mjera privrženosti i za oca i za majku i dobi male su, značajne i negativne te se kreću $u$ rasponu od $r=-0,10(p<0,05)$ do $-0,20$ ( $\mathrm{p}<0,01$ ), pri čemu mlađi sudionici procjenjuju privrženost i ocu i majci višom od starijih sudionika.

Mjere simetričnosti pokazale su da distribucije većine varijabli rizičnoga i delinkventnoga ponašanja značajno odstupaju od normalne distribucije te ovise o odstupanju simetričnosti primijenjene odgovarajuće statističke transformacije (Howell, 2006.; Tabachnick i Fidell, 2007.). Spolne razlike dobivene su na ukupnom rezultatu te na pet od sedam podljestvica upitnika SRDP-a, pri čemu su djevojke jedino na podljestvici Suicidalna i autoagresivna ponašanja postizale viši rezultat od mladića. U Tablici 3 prikazani su rezultati analiza samo za značajne razlike.

\begin{tabular}{|c|c|c|c|c|c|}
\hline \multirow[b]{2}{*}{ Podljestvice } & \multicolumn{2}{|c|}{ Mladići } & \multicolumn{2}{|c|}{ Dievojke } & \multirow[t]{2}{*}{$t$} \\
\hline & $\mathrm{M}$ & $\mathrm{SD}$ & $\mathrm{M}$ & $\mathrm{SD}$ & \\
\hline Prekršaji & 26,69 & 29,18 & 7,15 & 12,70 & $15,34^{* * *}$ \\
\hline Normativna nepoželjna & 18,06 & 11,06 & 15,34 & 10,19 & $4,34^{* * *}$ \\
\hline Zlouporaba psihoakt. tvari & 7,78 & 17,63 & 5,18 & 12,36 & $2,64^{* *}$ \\
\hline Teška kaznena djela & 5,15 & 13,57 & 1,50 & 6,41 & $5,90^{* * *}$ \\
\hline Suicid i autoagresija & 1,55 & 6,31 & 3,03 & 8,70 & $-4,04^{* * *}$ \\
\hline SRDP & 70,07 & 72,43 & 43,23 & 48,43 & $4,75^{* * *}$ \\
\hline
\end{tabular}

${ }^{* * *} \mathrm{p}<0,001 ;{ }^{* *} \mathrm{p}<0,01 ;{ }^{*} \mathrm{p}<0,05$

Slično prethodnim istraživanjima (npr. Demuth i Brown, 2004.; Derzon i Lipsey, 2000.; Kierkus i Baer, 2002.), dobivene su značajne razlike $u$ samoiskazanom rizičnom i delinkventnom ponašanju između sudionika koji žive $u$ jednoroditeljskim i dvoroditeljskim obiteljima. Na ukupnom rezultatu i na 
pet od sedam podljestvica sudionici iz jednoroditeljskih obitelji postizali su značajno viši rezultat od sudionika koji žive s oba roditelja. U Tablici 4 prikazane su značajne razlike.

\begin{tabular}{|c|c|c|c|c|c|}
\hline \multirow[b]{2}{*}{ Podljestvice } & \multicolumn{2}{|c|}{ Dvoroditeljska obitelj } & \multicolumn{2}{|c|}{ Jednoroditeljska obitelj } & \multirow[t]{2}{*}{$t$} \\
\hline & $\mathrm{M}$ & SD & $\mathrm{M}$ & $\mathrm{SD}$ & \\
\hline Prekršaji & 10,02 & 18,18 & 14,67 & 22,52 & $2,42^{*}$ \\
\hline Zlouporaba psihoakt. tvari & 5,91 & 14,36 & 9,72 & 16,85 & $2,51^{*}$ \\
\hline Nasilje & 6,24 & 18,26 & 10,02 & 21,25 & $1,98^{*}$ \\
\hline Teška kaznena djela & 1,89 & 8,26 & 4,24 & 6,95 & $2,86^{* *}$ \\
\hline Suicid i autoagresija & 4,13 & 9,85 & 7,96 & 12,73 & $3,62^{* * *}$ \\
\hline SRDP & 45,17 & 56,92 & 62,48 & 60,77 & $2,76^{* *}$ \\
\hline SRDP-SRDP ukupno & & & & & \\
\hline
\end{tabular}

${ }^{* *} \mathrm{p}<0,001 ;{ }^{* *} \mathrm{p}<0,01 ;{ }^{*} \mathrm{p}<0,05$

T TABLICA 4

Usporedba rezultata sudionika iz dvoroditeljskih i jednoroditeliskih obitelii na Upit niku SRDP-a
Na skalnim rezultatima izračunane su korelacije između dimenzija privrženosti ocu i dimenzija privrženosti majci i sedam faktora Upitnika SRDP-a, i to samo za sudionike koji žive $\mathrm{u}$ dvoroditeljskim obiteljima. U Tablici 5 prikazane su dobivene korelacije.

\begin{tabular}{lllllllll}
\hline & PovM & PovO & KomM & KomO & OtuđM & OtuđO & OpćaM & OpćaO \\
\hline 1 & $-0,10^{*}$ & $-0,13^{* *}$ & $-0,07$ & $-0,18^{* *}$ & $0,10^{*}$ & $0,18^{*}$ & $-0,11^{*}$ & $-0,18^{* *}$ \\
2 & $-0,13^{* *}$ & $-0,23^{* *}$ & $-0,18^{* *}$ & $-0,26^{* *}$ & $0,22^{* *}$ & $0,31^{* *}$ & $-0,22^{* *}$ & $-0,30^{* *}$ \\
3 & $-0,09^{*}$ & $-0,15^{* *}$ & $-0,12^{* *}$ & $-0,10^{*}$ & 0,07 & 0,07 & $-0,12^{*}$ & $-0,13^{* *}$ \\
4 & $-0,10^{*}$ & $-0,23^{* *}$ & $-0,13^{* *}$ & $-0,28^{* *}$ & $0,14^{* *}$ & $0,21^{* *}$ & $-0,13^{* *}$ & $-0,25^{* *}$ \\
5 & $-0,13^{* *}$ & $-0,21^{* *}$ & $-0,17^{* *}$ & $-0,20^{* *}$ & $0,14^{* *}$ & $0,15^{* *}$ & $-0,19^{* *}$ & $-0,24^{* *}$ \\
6 & $-0,15^{* *}$ & $-0,16^{* *}$ & $-0,10^{*}$ & $-0,17^{* *}$ & $0,11^{* *}$ & $0,12^{* *}$ & $-0,13^{* *}$ & $-0,14^{* *}$ \\
7 & $-0,25^{* *}$ & $-0,23^{* *}$ & $-0,25^{* *}$ & $-0,35^{* *}$ & $0,21^{* *}$ & $0,24^{* *}$ & $-0,27^{* *}$ & $-0,34^{* *}$ \\
SRDP & $-0,19^{* *}$ & $-0,31^{* *}$ & $-0,19^{* *}$ & $-0,36^{* *}$ & $0,21^{* *}$ & $0,31^{* *}$ & $-0,24^{* *}$ & $-0,36^{* *}$ \\
\hline
\end{tabular}

1 - Prekršajna i lakša delinkventna ponašanja; 2 - Nepoželjna normativna ponašanja; 3 - Rizična spolna ponašanja; 4 - Korištenje ili zlouporaba psihoaktivnih tvari; 5 - Nasilničko ponašanje u bliskim odnosima; 6 - Teške krađe, provale i razbojništvo; 7 - Suicidalna i autoagresivna ponašanja; SRDP-SRDP ukupno. ${ }^{* *} \mathrm{p}<0,001 ;{ }^{* *} \mathrm{p}<0,01 ;{ }^{*} \mathrm{p}<0,05$

(1) TABLICA 5 Povezanost dimenziia privrženosti i oblika rizičnoga i delinkventnoga ponašanja
Očekivano, dimenzije privrženosti Komunikacija i Povjerenje negativno su povezane, dok je dimenzija Otuđenost pozitivno povezana s oblicima rizičnoga i delinkventnoga ponašanja. Veličina i smjer povezanosti slični su onima dobivenima u prethodnim istraživanjima. Tako npr. rezultati istraživanja Rankina i Kerna (1994.) također pokazuju da su ukupni rezultat i dimenzije privrženosti najmanje povezani s težim oblicima delinkventnoga ponašanja (npr. teške krađe, provale i razbojništvo), dok su najviše povezane sa suicidalnim i autoagresivnim ponašanjem. Nadalje, korelacije između mjera privrženosti za oca i oblika rizičnoga i delinkventnoga ponašanja konzistentno su veće od onih dobivenih za majku. 


\section{Spol kao moderator}

Da bismo ispitali ulogu spola kao moderatora efekata dimenzija privrženosti na izraženost pojedinih oblika rizičnoga i delinkventnoga ponašanja, proveden je niz hijerarhijskih regresijskih analiza. Kako bi se smanjio problem multikolinearnosti, dimenzije privrženosti su centrirane, odnosno, interakcijski efekti izračunani su kao umnošci devijacijskih rezultata između dvaju skupova nezavisnih varijabli. Analize su provedene zasebno za oca i za majku. Pojedini oblici rizičnoga i delinkventnoga ponašanja (osam oblika) uključeni su kao zavisne varijable, dok su u svim analizama kao nezavisne varijable u prvom koraku uključene demografske varijable (spol, dob i socioekonomski status), u drugom koraku dimenzije privrženosti ili opća privrženost, a u trećem koraku interakcije između spola i dimenzija privrženosti/opće privrženosti. U Tablici 6 i Tablici 7 prikazani su rezultati tih analiza, pri čemu su navedeni samo oni oblici rizičnoga i delinkventnoga ponašanja za koje su utvrđene značajne interakcije.

$\rightarrow$ TABLICA 6

Rezultati hijerarhijskih regresijskih analiza za privrženost ocu

\begin{tabular}{|c|c|c|c|}
\hline Model & Varijable & $\beta$ & $\mathrm{R}^{2}$ (sig F change \\
\hline \multicolumn{4}{|c|}{ Prekršajna i lakša delinkventna ponašanja } \\
\hline 1. korak & $\begin{array}{l}\text { Spol } \\
\text { Dob }\end{array}$ & $\begin{array}{r}-0,39 * * * \\
0,20^{* * *}\end{array}$ & 0,18 \\
\hline 2. korak & OpćaO & $-0,19 * * *$ & $0,22^{* * *}$ \\
\hline 3. korak & Spol x OpćaO & $0,25^{* *}$ & $0,24^{* *}$ \\
\hline \multicolumn{4}{|c|}{ Korištenje ili zlouporaba psihoaktivnih tvari } \\
\hline 1. korak & $\begin{array}{l}\text { Spol } \\
\text { Dob }\end{array}$ & $\begin{array}{c}-0,13^{* *} \\
0,19^{* * *}\end{array}$ & 0,05 \\
\hline 2. korak & OpćaO & $-0,23^{* * *}$ & $0,10^{* * *}$ \\
\hline 3. korak & Spol x OpćaO & $0,18^{*}$ & $0,12^{*}$ \\
\hline \multicolumn{4}{|c|}{ Teške krađe, provale i razbojništvo } \\
\hline $\begin{array}{l}\text { 1. korak } \\
\text { 2. korak } \\
\text { 3. korak }\end{array}$ & $\begin{array}{l}\text { Spol } \\
\text { OpćaO } \\
\text { Spol x OpćaO }\end{array}$ & $\begin{array}{r}-0,13^{* *} \\
-0,15^{* *} \\
0,28^{* *}\end{array}$ & $\begin{array}{l}0,02 \\
0,05^{* *} \\
0,07^{* *}\end{array}$ \\
\hline \multicolumn{4}{|c|}{ SRDP ukupno } \\
\hline 1. korak & $\begin{array}{l}\text { Spol } \\
\text { Dob }\end{array}$ & $\begin{array}{c}-0,018^{* * *} \\
0,31^{* * *}\end{array}$ & 0,13 \\
\hline 2. korak & OpćaO & $-0,34^{* * *}$ & $0,24^{* * *}$ \\
\hline 3. korak & Spol x OpćaO & $0,19^{* *}$ & $0,25^{*}$ \\
\hline
\end{tabular}

${ }^{* * *} \mathrm{p}<0,001 ;{ }^{* *} \mathrm{p}<0,01 ;{ }^{*} \mathrm{p}<0,05$

Interakcije privrženosti ocu i spola pokazale su se značajnim prediktorima faktora kojima se mjere oblici delinkventnoga ponašanja, tj. faktora Prekršajna i lakša delinkventa ponašanja, Korištenje ili zlouporabu psihoaktivnih tvari, Teške 
DRUŠ. ISTRAŽ. ZAGREB GOD. 20 (2011), BR. 1 (111)

STR. 167-187

RUČEVIĆ, S.:

POVEZANOST..

- TABLICA 7

Rezultati hijerarhijskih regresijskih analiza za privrženost majci
O SLIKA 1

Interakcijski efekt opće privrženosti ocu i spola dieteta na ukupnu mieru delinkventnoga ponašanja (dvoroditeliske obitelii) krađe, provale i razbojništva i SRDP-a ukupno. Sve značajne interakcije pokazuju da izraženost delinkventnoga ponašanja s povećanjem privrženosti ocu više opada kod mladića nego kod djevojaka. Na Slici 1 prikazan je interakcijski efekt spomenutih varijabli na ukupnu mjeru rizičnog i delinkventnoga ponašanja (SRDP ukupno).

\begin{tabular}{llll}
\hline Model & Varijable & $\beta$ & $R^{2}$ (sig F change) \\
\hline
\end{tabular}

Prekršajna i lakša delinkventna ponašanja

$\begin{array}{llcl}\text { 1. korak } & \text { Spol } & -0,39^{* * *} & 0,18 \\ & \text { Dob } & 0,20^{* * *} & \\ \text { 2. korak } & \text { OpćaM } & -0,14^{* *} & 0,20^{* *} \\ \text { 3. korak } & \text { Spol x OpćaM } & 0,28^{* *} & 0,22^{* *}\end{array}$

Korištenje ili zlouporaba psihoaktivnih tvari

$\begin{array}{llcl}\text { 1. korak } & \text { Spol } & -0,13^{* *} & 0,05 \\ & \text { Dob } & 0,19^{* * *} & \\ \text { 2. korak } & \text { OpćaM } & -0,15^{* *} & 0,08^{* *} \\ \text { 3. korak } & \text { Spol x OpćaM } & - & - \\ \text { Teške krađe, provale i razbojništvo } & & \\ \text { 1. korak } & \text { Spol } & -0,13^{* *} & 0,02 \\ \text { 2. korak } & \text { OpćaM } & -0,14^{* *} & 0,04^{* *} \\ \text { 3. korak } & \text { Spol x OpćaM } & 0,32^{* *} & 0,07^{* * *} \\ \text { SRDP ukupno } & & \\ \text { 1. korak } & \text { Spol } & -0,18^{* * *} & 0,13 \\ & \text { Dob } & 0,31^{* * *} & \\ \text { 2. korak } & \text { OpćaM } & -0,25^{* * *} & 0,19^{* * *} \\ \text { 3. korak } & \text { Spol x OpćaM } & 0,20^{*} & 0,20^{*} \\ \end{array}$

${ }^{* * *} \mathrm{p}<0,001 ;{ }^{* *} \mathrm{p}<0,01 ;{ }^{*} \mathrm{p}<0,05$

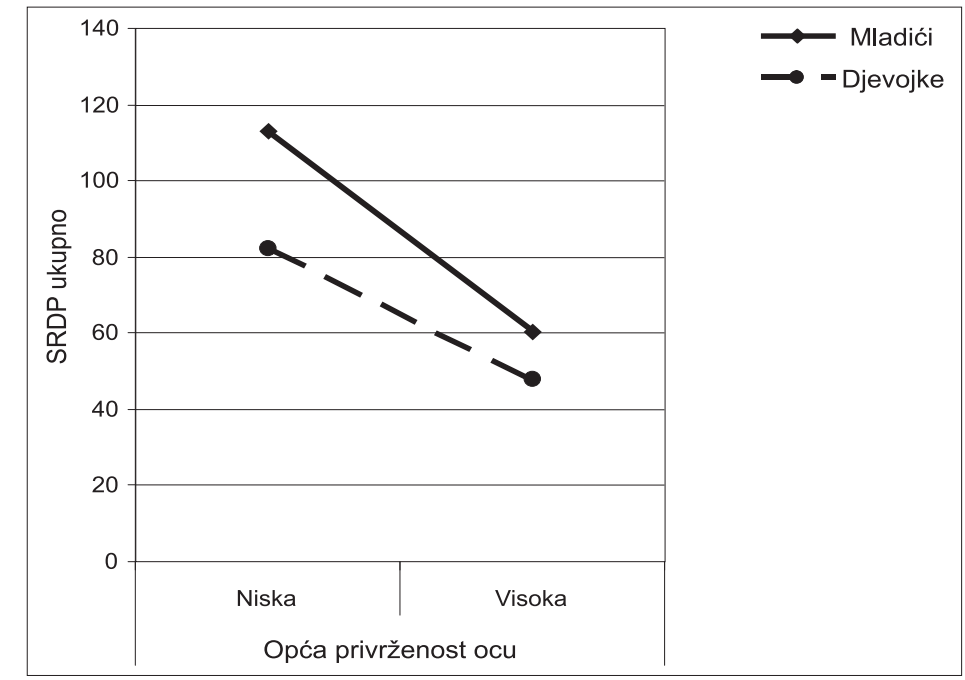


DRUŠ. ISTRAŽ. ZAGREB GOD. 20 (2011), BR. 1 (111)

STR. 167-187

RUČEVIĆ, S.

POVEZANOST.

O SLIKA 2

Interakcijski efekt opće privrženosti majci i spola dieteta na ukupnu mieru delinkventnog ponašanja (dvoroditeliske obitelii)
$\mathrm{Na}$ isti je način s raznim oblicima delinkventnoga ponašanja povezana i interakcija opće privrženosti majci i spola. Dakle, efekti privrženosti majci na izraženost delinkventnoga ponašanja veći su kod mladića nego kod djevojaka. Interakcijski efekt opće privrženosti majci i spola na ukupnu mjeru rizičnoga i delinkventnoga ponašanja (SRDP ukupno) prikazan je na Slici 2.

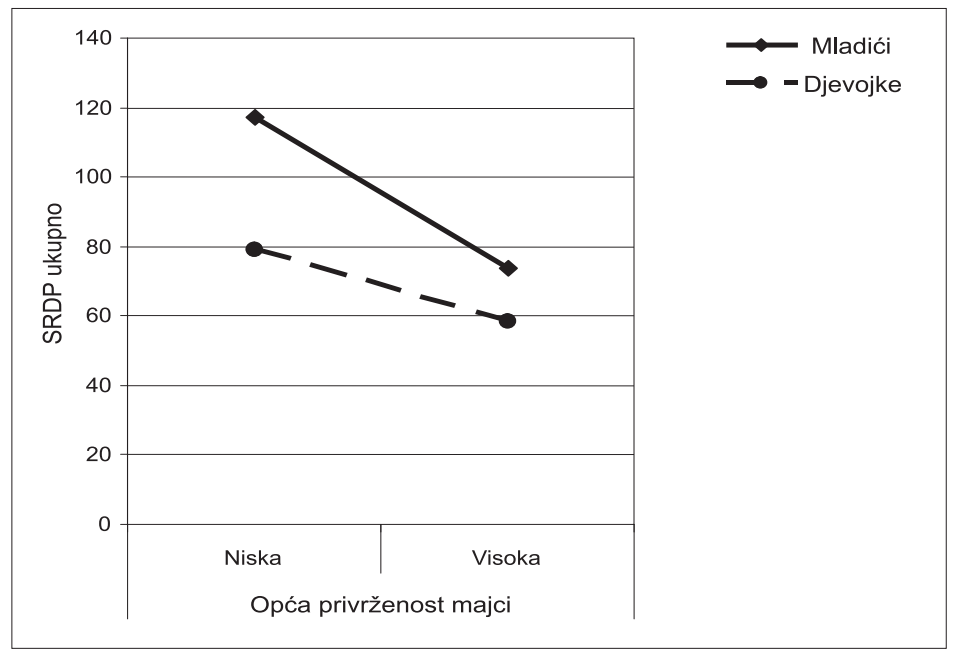

Uz opće mjere privrženosti provjereni su i interakcijski efekti dimenzija privrženosti i spola. Međutim, ni jedna od interakcija nije se pokazala značajnim prediktorom raznih oblika rizičnoga i delinkventnoga ponašanja.

\section{Privrženost u dvoroditeljskim obiteljima}

Nadalje, testirali smo ima li privrženost dvama roditeljima dodatni inhibitorni učinak na delinkventno ponašanje u odnosu na privrženost samo jednom roditelju. Jedan od načina da se odgovori na ovo pitanje jest da se u regresijsku analizu, uz zasebne mjere privrženosti ocu i privrženosti majci, uključi interakcija ovih dviju mjera (uz kontroliranje efekata spola, dobi i socioekonomskoga statusa). Od 32 regresijska modela (8 mjera rizičnoga i delinkventnoga ponašanja x 4 mjere privrženosti ocu/majci) samo je u jednom modelu interakcijski efekt bio značajan. Interakcijski efekt između dimenzije Komunikacije za majku i dimenzije Komunikacije za oca pokazao se značajnim prediktorom prekršajnih i lakših delinkventnih ponašanja $(\beta=-0,11, p<0,05)$. Pri tome su sudionici koji su izvještavali o kvalitetnijoj komunikaciji s ocem i majkom ujedno izvještavali i o manjem broju prekršajnih i kaznenih djela. Dobiveni rezultati idu u prilog Hirschijevoj hipotezi da privrženost jednom roditelju podjednako inhibira delinkventno ponašanje kao i privrženost dvama roditeljima. Međutim, o- 
DRUŠ. ISTRAŽ. ZAGREB GOD. 20 (2011), BR. 1 (111)

STR. 167-187

RUČEVIĆ, S.: POVEZANOST.. vim postupkom dobiven je uvid u globalne ili opće interakcije. Naime, ovakvim je postupkom svih pet stupnjeva Likertove skale - za majku u interakciji sa svih pet stupnjeva Likertove skale - za oca. Kao rezultat toga, djeca koja su visoko privržena ocu ne moraju biti i djeca koja su visoko privržena majci. S obzirom na to da se ispituje specifična hipoteza, odnosno, ako je dijete visoko privrženo jednom roditelju hoće li visoka privrženost i drugom roditelju imati dodatni inhibitorni učinak na manifestiranje nekog od oblika rizičnoga i delinkventnoga ponašanja, bilo je potrebno rekodirati mjere privrženosti za oca i majku. Mjere privrženosti rekodirane su u dummy varijable tako da odgovori na česticama " 4 - uglavnom točno" i " 5 - gotovo uvijek ili uvijek točno" odražavaju visoku privrženost, dok odgovori "1 - gotovo nikad ili nikad nije točno" i "2 - uglavnom netočno" odražavaju nisku privrženost. Nadalje, identične čestice objedinjene su u jednu mjeru. $\mathrm{Na}$ primjer, umjesto dvije mjere komunikacije (jedna za majku i jedna za oca), nakon rekodiranja dobivena je dimenzija komunikacija sa sljedećim kategorijama dummy varijable koje odražavaju privrženost roditeljima: (1) niska/niska, (2) niska/ visoka i (3) visoka/visoka. Kategorija niska/visoka referentna je grupa s kojom se uspoređuju koeficijenti preostalih grupa, pa ona nije uključena u regresijsku analizu. Ako koeficijent za neku kategoriju nije statistički značajan, tada se efekti te kategorije na zavisnu varijablu i efekti referentne kategorije (one koja nije uključena u regresijsku analizu) ne razlikuju značajno (Tabachnick i Fidell, 2007.). Na primjer, ako visoka povezanost jednom roditelju (kategorija niska/visoka) inhibira delinkventno ponašanje jednako uspješno kao i visoka privrženost dvama roditeljima (kategorija visoka/visoka), tada regresijski koeficijenti za kategoriju visoka/visoka neće biti statistički značajni. S druge strane, ako su koeficijenti za kategoriju visoka/visoka statistički značajni, tada visoka privrženost dvama roditeljima ima dodatni inhibirajući efekt na delinkventno ponašanje. Od 32 regresijska modela samo su tri koeficijenta za kategoriju visoka/visoka bila značajna, što ide u prilog Hirschijevoj pretpostavci da visoka privrženost jednom roditelju ima podjednak inhibirajući učinak kao i privrženost dvama roditeljima.

\section{Privrženost $u$ domovima u kojima je skrbnik majka (jednoroditeljski domovi)}

Naposljetku, provjerena je hipoteza da je visoka privrženost roditelju skrbniku u jednoroditeljskom domu podjednako učinkovita u inhibiranju rizičnoga i delinkventnoga ponašanja kao i visoka privrženost dvama roditeljima u dvoroditeljskim obiteljima. S obzirom na postavljenu hipotezu, analiza je bila 
DRUŠ. ISTRAŽ. ZAGREB GOD. 20 (2011), BR. 1 (111)

STR. 167-187

RUČEVIĆ, S. POVEZANOST.

ograničena na (1) mlade koji žive u dvoroditeljskim obiteljima te koji su visoko privrženi barem jednom roditelju i (2) mlade koji žive $\mathrm{u}$ jednoroditeljskim domovima koji su visoko privrženi roditelju skrbniku. Ovdje se uspoređuju koeficijenti kategorija za visoku privrženost jednom roditelju (niska/visoka) i visoku privrženost dvama roditeljima (visoka/visoka) u dvoroditeljskim obiteljima s referentnom kategorijom visoke privrženosti roditelju skrbniku u jednoroditeljskoj obitelji. Ako visoka privrženost roditelju skrbniku ima podjednak inhibirajući učinak na manifestaciju rizičnoga i delinkventnoga ponašanja kao i visoka privrženost dvama roditeljima u dvoroditeljskim obiteljima, tada koeficijenti za kategoriju visoka/visoka neće biti statistički značajni. Međutim, ako privrženost dvama roditeljima ima dodatni inhibirajući učinak u odnosu na privrženost roditelju skrbniku u jednoroditeljskim obiteljima, tada će koeficijenti za kategoriju visoka/visoka biti statistički značajni (i negativni). U 32 regresijska modela (uz kontroliranje efekata dobi, spola i socioekonomskoga statusa) dobiveno je samo šest značajnih (negativnih) koeficijenata za kategoriju visoka/visoka privrženost, što ponovno ide u prilog Hirschijevoj hipotezi.

\section{RASPRAVA}

Rezultati ovog istraživanja pokazuju da su mjere privrženosti roditeljima nisko do umjereno, ali konzistentno povezane s različitim oblicima rizičnoga i delinkventnoga ponašanja.

Suprotno očekivanjima, dobiveni su različiti efekti privrženosti ocu i privrženosti majci na delinkventno ponašanje mladića i djevojaka. Iako su mladići izvještavali o većem broju pojavnih oblika delinkventnoga ponašanja od djevojaka, efekti privrženosti majci i privrženosti ocu na delinkventno ponašanje bili su veći kod mladića. Odnosno, izraženost delinkventnoga ponašanja s povećanjem privrženosti ocu i privrženosti majci više je opadala kod mladića nego kod djevojaka (Slika 1 i 2). Ovi rezultati dovode u pitanje dosadašnje pretpostavke o važnosti pojedinih čimbenika rizika za razvoj delinkventnoga ponašanja kod djevojaka i mladića. Naime, u prethodnim istraživanjima često se naglašavala uloga obiteljskih čimbenika, tj. obiteljske strukture i privrženosti roditeljima, pod pretpostavkom da ove varijable imaju izraženije efekte na delinkventno ponašanje djevojaka u odnosu na mladiće. Uobičajeno je mišljenje da djevojke uspostavljaju bliskije odnose s roditeljima te da su zbog toga manje sklone kršiti roditeljska pravila (Archer i Lloyd, 2002.). Iako su istraživanja pokazala da djevojke zaista uspostavljaju bliskije odnose s članovima obitelji te da je roditeljski nadzor veći za ponašanje djevojaka, efekti tog odnosa izraženiji su kod mladića nego 
DRUŠ. ISTRAŽ. ZAGREB GOD. 20 (2011), BR. 1 (111)

STR. 167-187

RUČEVIĆ, S.: POVEZANOST.. kod djevojaka (npr. Anderson i sur., 1999.; Cernkovich i Giordano, 1987.). Jedno od mogućih objašnjenja jest da su oblici indirektne kontrole, npr. privrženost roditeljima, važniji za mladiće nego za djevojke, jer mladići provode više vremena izvan obitelji i bez roditeljskoga nadzora te zbog toga oblici indirektne kontrole smanjuju vjerojatnost javljanja delinkventnoga ponašanja kod mladića, ali ne i kod djevojaka (Jang i Krohn, 1995.; Sampson i Laub, 1994.; Seydlitz, 1991.). Zanimljivo je da, za razliku od težih oblika delinkventnoga ponašanja, nisu dobivene spolne razlike u povezanosti privrženosti roditeljima i rizičnih ponašanja te nasilja u bliskim odnosima (nasilje prema roditeljima i romantičnom partneru). Nadalje, ni jedna od dimenzija privrženosti upotrijebljenih u ovom istraživanju nije bila konzistentno značajan prediktor oblika rizičnoga i delinkventnoga ponašanja.

U skladu s hipotezom, rezultati ovog istraživanja pokazuju da visoka privrženost jednom roditelju podjednako učinkovito inhibira delinkventno ponašanje kao i visoka privrženost dvama roditeljima. Iako je moguće da je sličnost među procjenama privrženosti dvama roditeljima rezultat upotrijebljene mjere privrženosti (samoprocjena), prethodna istraživanja pokazala su da je sličnost privrženosti dvama roditeljima povezana sa sličnim roditeljskim stilovima (npr. Fox i sur., 1991.) te da kvaliteta privrženosti jednom roditelju djeluje na kvalitetu privrženosti drugom roditelju (Bowlby, 1982.; Steele i sur., 1996.).

Nadalje, rezultati ovog istraživanja pokazuju da su sudionici koji žive $u$ jednoroditeljskim obiteljima izvještavali o većem broju pojavnih oblika rizičnoga i delinkventnoga ponašanja nego oni koji žive $u$ dvoroditeljskim obiteljima. Po mišljenju nekih autora, odrastanje u jednoroditeljskim obiteljima povezano je s izraženijim delinkventnim ponašanjem mladih zbog privrženosti samo jednom roditelju (npr. Rankin i Kern, 1994.; Rankin i Wells, 1990.; Wells i Rankin, 1991.). Međutim, rezultati ovog istraživanja pokazuju da je visoka privrženost roditelju skrbniku u jednoroditeljskom domu podjednako učinkovita u kontroliranju rizičnoga i delinkventnoga ponašanja kao i visoka privrženost dvama roditeljima u dvoroditeljskim obiteljima. Jedno od mogućih objašnjenja dobivenih rezultata jest da na odnos između privrženosti roditeljima i rizičnoga i delinkventnoga ponašanja, direktno ili indirektno, djeluju i neki drugi procesi unutar obitelji. Naime, istraživanja su pokazala da je vrlo važan prediktor privrženosti roditeljima, ali i delinkventnoga ponašanja, odnos među roditeljima, tj. postojanje sukoba među njima (Capaldi i Patterson, 1991.; Crockett i sur., 1993.; DeKlyen i sur., 1998.; Gorman-Smith i sur., 1999.; Matsueda i Heimer, 1987.; McCord, 1991.). 
DRUŠ. ISTRAŽ. ZAGREB GOD. 20 (2011), BR. 1 (111)

STR. 167-187

RUČEVIĆ, S. POVEZANOST..
Na primjer, Joan McCord (1990.) uspoređivala je učinke roditeljskoga sukoba u dvoroditeljskim obiteljima s učincima života samo s jednim roditeljem na ponašanje mladića. U usporedbi s mladićima koji su odrastali u dvoroditeljskim obiteljima u kojima je postojao sukob među roditeljima mladići koji su odrastali $\mathrm{u}$ jednoroditeljskim domovima s brižnom majkom bili su upola manje puta osuđeni za počinjenje teškoga kaznenog djela. Nisu dobivene ni razlike s obzirom na rizično i delinkventno ponašanje između mladića koji su živjeli u dvoroditeljskim stabilnim obiteljima i mladića koji su živjeli $\mathrm{u}$ jednoroditeljskim obiteljima s brižnom majkom.

Ukupno uzevši, rezultati ovog istraživanja pokazuju da je niska kvaliteta privrženosti povezana s većim brojem oblika rizičnoga i delinkventnoga ponašanja. Utvrđen je i efekt spola na odnos između privrženosti i rizičnoga i delinkventnoga ponašanja, pri čemu izraženost delinkventnoga ponašanja s povećanjem privrženosti ocu i majci više opada kod mladića nego kod djevojaka. Dobiveni rezultati također pokazuju da broj roditelja kojima je mlada osoba visoko privržena nema aditivni učinak, što je u skladu s Hirschijevom hipotezom.

$\mathrm{Na}$ kraju treba napomenuti da dobivene rezultate treba promatrati i u kontekstu nekih nedostataka ovoga istraživanja. Prije svega ono je provedeno transverzalno i potpuno se temelji na podacima dobivenim samoprocjenama.

Nadalje, već spomenuta istraživanja (npr. McCord, 1991.) pokazala su da nakon kontrole efekta odnosa među roditeljima, tj. postojanja sukoba, nema značajne razlike $u$ rizičnom $i$ delinkventnom ponašanju između adolescenata koji žive u jednoroditeljskim i dvoroditeljskim obiteljima. Pod tim je jedan od nedostataka ovog istraživanja taj što nisu prikupljeni podaci o tome kakav je odnos mladih iz jednoroditeljskih obitelji s roditeljem s kojim ne žive te koliko su često u kontaktu s tim roditeljem. Nisu prikupljeni ni podaci o tome je li mlada osoba razvila visoku (alternativnu) privrženost nekoj drugoj osobi koja može preuzeti ulogu "zamjenskog" roditelja (npr. baka, djed ili novi partner roditelja skrbnika) te na koji je način ta "nova" privrženost povezana s rizičnim i delinkventnim ponašanjem. Prethodna istraživanja pokazala su da razvijanje privrženosti prema "zamjenskim" osobama ima inhibitorni učinak na antisocijalno ponašanje djece i mladih (npr. Howes, 1999.).

U budućim bi se istraživanjima svakako uz mjere privrženosti roditeljima trebale uvrstiti i mjere privrženosti vršnjacima, čime bi se dobio uvid u interakciju između obitelji i vršnjaka i razjasnio "zaštitni" učinak privrženosti roditeljima na javljanje rizičnoga i delinkventnoga ponašanja. Trebalo bi ispitati i povezanost kvalitete i stilova privrženosti te njihovu relativnu važnost u pojavi i razvoju rizičnoga i delinkventnoga ponašanja, posebno u kontekstu spolnih razlika. 


\section{LITERATURA}

Ajduković, M., Ručević, S. i Šincek, D. (2009.), Razvoj upitnika samoiskaza rizičnog i delinkventnog ponašanja mladih (SRDP-2007). Kriminologija i socijalna integracija, 17 (1): 1-96.

Anderson, B. J., Holmes, D. i Malcom, O. E. (1999.), Male and Female Delinquents' Attachments and Effects of Attachments on Severity of Self-Reported Delinquency. Criminal Justice and Behavior, 26 (4): 435-452.

Archer, J. i Lloyd, B. (2002.), Sex and Gender, Cambridge, UK: Cambridge University Press.

Armsden, G. C. i Greenberg, M. T. (1987.), The Inventory of Parent and Peer Attachment: Individual Differences and Their Relationship to Psychological Well-Being in Adolescence. Journal of Youth and Adolescence, 16 (5): 427-454.

Berlin, L. i Cassidy, J. (1999.), Relations among Relationships: Contributions from Attachment Theory and Research. U: J. Cassidy i P. R. Shaver (ur.), Handbook of Attachment: Theory, Research and Clinical Applications (str. 368-712), New York, The Guilford Press.

Bowlby, J. (1982.), Attachment and Loss: Vol. 2. Attachment (2nd ed.), New York: Basic Books.

Canter, R. (1982.), Family Correlates of Male and Female Delinquency. Criminology, 20 (2): 149-167.

Capaldi, D. M. i Patterson, G. R. (1991.), Relations of Parental Transition to Boys' Adjustment Problems: I. A Linear Hypothesis. II. Mothers at Risk for Transitions and Unskilled Parenting. Developmental Psychology, 27 (3): 489-504.

Cernkovich, S. A. i Giordano, P. C. (1987.), Family Relationships and Delinquency. Criminology, 25 (2): 295-319.

Chen, Z. Y. i Kaplan, H. B. (1997.), The Impact of Family Structure during Adolescence on Deviance in Early Adulthood. Deviant Behavior: An Interdisciplinary Journal, 18 (4): 365-391.

Cota-Robles, S. i Gamble, W. C. (2006.), Parent-Adolescent Processes and Reduced Risk for Delinquency: The Effect of Gender for Mexican American Adolescents. Youth E Society, 37 (4): 375-392.

Crockett, L. J., Eggebeen, D. J. i Hawkins, A. J. (1993.), Father's Presence and Young Children's Behavioral and Cognitive Adjustment. Journal of Family Issues, 14 (3): 355-377.

DeKlyen, M., Speltz, M. L. i Greenberg, M. T. (1998.), Fathering and Early Onset Conduct Problems: Positive and Negative Parenting, Father-Son Attachment, and the Marital Context. Clinical Child and Family Psychology Review, 1 (1): 3-21.

Demuth, S. i Brown, S. (2004.), Family Structure, Family Processes, and Adolescent Delinquency: The Significance of Parental Absence Versus Parental Gender. Journal of Research in Crime and Delinquency, 41 (1): 58-81.

Derzon, J. H. i Lipsey, M. W. (2000.), The Correspondence of Family Features with Problem, Aggressive, Criminal and Violent Behavior, Nashville: Institute for Public Policy Studies. 
DRUŠ. ISTRAŽ. ZAGREB GOD. 20 (2011), BR. 1 (111)

STR. 167-187

RUČEVIĆ, S.: POVEZANOST.
Eme, R. F. i Kavanaugh, L. (1995.), Sex Differences in Conduct Disorder. Journal of Clinical Child Psychology, 24 (4): 406-426.

Farrington, D. P. (1997.), Early Prediction of Violent and Non-Violent Youthful Offending. European Journal on Criminal Policy and Research, 5 (2): 51-66.

Farrington, D. P., Jolliffe, D., Hawkins, J. D., Catalano, R. F., Hill, K. G. i Kosterman, R. (2000.), Comparing Delinquency Careers in Court Records and Self-Reports, Cambridge University (neobjavljeni rukopis). Farrington, D. P. i Welsh, B. C. (2007.), Saving Children from a Life of Crime: Early Risk Factors and Effective Interventions, Oxford: Oxford University Press.

Farrington, D. P. i West, D. J. (1990.), The Cambridge Study in Delinquent Behaviour: A Long Term Follow-Up of 411 London Males. U: H. J. Kerner i G. Kaiser (ur.), Criminality: Personality, Behaviour, Life History (str. 115-138), Berlin, Springer-Verlag.

Fox, N. A., Kimmerly, N. L. i Schafer, W. D. (1991.), Attachment to Mother/Attachment to Father: A Meta-Analysis. Child Development, 62 (1): 210-225.

Goetting, A. (1994.), The Parenting-Crime Connection. The Journal of Primary Prevention, 14 (3): 169-186.

Gorman-Smith, D., Tolan, P. H. i Henry, D. (1999.), The Relation of Community and Family to Risk among Urban-Poor Adolescents. U: P. Cohen, L. Robins i C. Slomkowski (ur.), Where and When: Influence of Historical Time and Place on Aspects of Psychopathology (str. 349-367), Hillsdale, NJ, Lawrence Erlbaum Associates.

Gottfredson, D. C., McNeil, R. J. i Gottfredson, G. D. (1991.), Social Area Influences on Delinquency: A Multilevel Analysis. Journal of Research in Crime and Delinquency, 28 (2): 197-226.

Hirschi, T. (1969.), Causes of Delinquency, Berkeley: University of California Press.

Howell, D. C. (2006.), Statistical Methods for Psychology (6th ed.), New York: Wadsworth Pub Co.

Howes, C. (1999.), Attachment Relationships in the Context of Multiple Caregivers. U: J. Cassidy i P. R. Shaver (ur.), Handbook of Attachment: Theory, Research and Clinical Applications (str. 671-687), New York, The Guilford Press.

Hu, L. i Bentler, P. M. (1999.), Cutoff Criteria for Fit Indexes in Covariance Structure Analysis: Conventional Criteria Versus New Alternatives. Structural Equation Modeling, 6 (1): 1-55.

Jang, S. J. i Krohn, M. D. (1995.), Developmental Patterns of Sex Differences in Delinquency among African American Adolescents: A Test of the Sex-Invariance Hypothesis. Journal of Quantitative Criminology, 11 (2): 195-222.

Jolliffe, D., Farrington, D. P., Hawkins, J. D., Catalano, R. F., Hill, K. G. i Kosterman, R. (2003.), Predictive, Concurrent, Prospective and Retrospective Validity of Self-Reported Delinquency. Criminal Behaviour and Mental Health, 13 (3): 179-197.

Junger-Tas, J. (1992.), An Empirical Test of Social Control Theory. Journal of Quantitative Criminology, 8 (1): 9-28. 
DRUŠ. ISTRAŽ. ZAGREB GOD. 20 (2011), BR. $1(111)$ STR. 167-187

RUČEVIĆ, S.: POVEZANOST..
Junger-Tas, J. i Marshall, I. H. (1999.), The Self-Report Methodology in Crime Research. U: M. Tonry (ur.), Crime and Justice. A Review of Research, Vol. 25 (str. 291-367), Chicago, The University of Chicago.

Kierkus, C. i Baer, D. (2002.), A Social Control Explanation of the Relationship between Family Structure and Delinquent Behavior. $\mathrm{Ca}$ nadian Journal of Criminology, 44 (4): 425-458.

Leadbeater, B. J., Kuperminc, G. P., Blatt, S. J. i Hertzog, C. (1999.), A Multivariate Model of Gender Differences in Adolescents' Internalizing and Externalizing Problems. Developmental Psychology, 35 (5): 1268-1282

Mak, A. S. (1991.), Psychosocial Control Characteristics of Delinquents and Nondelinquents. Criminal Justice and Behavior, 18 (3): 287-303.

Matsueda, R. L. i Heimer, K. (1987.), Race, Family Structure, and Delinquency: A Test of Differential Association and Social Control Theories. American Sociological Review, 52 (6): 826-840.

McCord, J. (1990.), Long-Term Perspectives on Parental Absence. U: L. N. Robins i M. Rutter (ur.), Straight and Devious Pathways from Childhood to Adulthood (str. 116-134), Cambridge: UK, Cambridge University Press.

McCord, J. (1991.), Family Relationships, Juvenile Delinquency, and Adult Criminality. Criminology, 29 (3): 397-417.

Mikšaj-Todorović, Lj. (2004.), Kriminalno ponašanje. U: J. Bašić, N. Koller-Trbović i S. Uzelac (ur.), Poremećaji u ponašanju: pristupi i pojmovna određenja (str. 37-45), Zagreb, Edukacijsko-rehabilitacijski fakultet.

Moffitt, T. E. (2006.), Life-Course Persistent Versus AdolescenceLimited Antisocial Behavior. U: D. Cicchetti i D. J. Cohen (ur.), Developmental Psychopathology, Vol. 3: Risk, disorder, and adaptation (str. 570-598), New York, Wiley.

Moffitt, T. E., Caspi, A., Rutter, M. i Silva, P. A. (2001.), Sex Differences in Antisocial Behavior: Conduct Disorder, Delinquency, and Violence in the Dunedin Longitudinal Study, Cambridge: UK, Cambridge University Press.

Nelson, S. M. i Rubin, S. (1997.), Sex Differences, Parental Attachment, and Juvenile Delinquency. Journal of Police and Criminal Psycho$\log y, 12$ (2): 28-34.

Piquero, A. R., Farrington, D. P. i Blumstein, A. (2007.), Key Issues in Criminal Career Research, Cambridge, UK: Cambridge University Press.

Rankin, J. H. i Kern, R. (1994.), Parental Attachments and Delinquency. Criminology, 32 (4): 495-515.

Rankin, J. H. i Wells, L. E. (1990.), The Effect of Parental Attachments and Direct Controls on Delinquency. Journal of Research in Crime and Delinquency, 27 (2):140-165.

Sampson, R. J. i Laub, J. H. (1994.), Urban Poverty and the Family Context of Delinquency: A New Look at Structure and Process in a Classic Study. Child Development, 65 (2, Specijalni broj): 523-540.

Seydlitz, R. (1991.), The Effects of Age and Gender on Parental Control and Delinquency. Youth E Society, 23 (2): 175-201. 
DRUŠ. ISTRAŽ. ZAGREB GOD. 20 (2011), BR. 1 (111)

STR. 167-187

RUČEVIĆ, S. POVEZANOST.
Sokol-Katz, J., Dunham, R. i Zimmerman, R. (1997.), Family Structure Versus Parental Attachment in Controlling Adolescent Deviant Behavior: A Social Control Model. Adolescence, 32 (125): 199-215.

Steele, H., Steele, M. i Fonagy, P. (1996.), Associations among Attachment Classifications of Mothers, Fathers, and their Infants: Evidence for a Relationship-Specific Perspective. Child Development, 67 (2): 541-555.

Šućur, Z. (2004.), Pojam i tipologija društvenih devijacija: sociološka perspektiva. U: J. Bašić, N. Koller-Trbović i S. Uzelac (ur.), Poremećaji u ponašanju: pristupi i pojmovna određenja (str. 15-35), Zagreb, Edukacijsko-rehabilitacijski fakultet.

Tabachnick, B. i Fidell, L. (2007.), Using Multivariate Statistics (5th ed.), New York: Pearson.

Thornberry, T. P. i Krohn, M. D. (2000.), The Self-Report Method for Measuring Delinquency and Crime. http://www.ncjrs.gov/criminal justice2000/vol 4/04b.pdf (15. 11. 2007.)

Van Voorhis, P., Cullen, F. T., Mathers, R. A. i Garner, C. C. (1988.), The Impact of Family Structure and Quality on Delinquency: A Comparative Assessment of Structural and Functional Factors. Criminology, 26 (2): 235-261.

Wasserman, G. A. i Seracini, A. M. (2001.), Family Risk Factors and Interventions. U: R. Loeber i D. P. Farrington (ur.), Child Delinquents: Development, Intervention, and Service Needs (str. 165-169), Thousand Oaks, Sage.

Wells, E. L. i Rankin, J. H. (1991.), Families and Delinquency: A MetaAnalysis of the Impact of Broken Homes. Social Problems, 38 (1): 71-93.

\section{Relationship between Parental Attachments and Delinquent and Risk-Taking Behaviors}

Silvija RUČEVIĆ

Faculty of Philosophy, Osijek

The current study examined the association of attachment analyzed along several dimensions (i.e. communication, trust and alienation) and severity of delinquent and risk-taking behaviors in a non-referred sample of boys $(n=226)$ and girls $(n=480)$, aged 13-19. Specifically, it examined (a) the role of gender as a moderator in the effect of separate parental attachments on severity of delinquent and risk-taking behaviors, and (b) the effect of the number of strong parent-adolescent attachments on severity of delinquent and risk-taking behaviors. Attachment and delinquent and risk-taking behaviors were assessed through self-report ratings. Generally, it was found that gender moderated the relationship between separate parental attachments and delinquent, but not risk-taking behaviors. Further investigation demonstrated that strong attachment to both mother and 
DRUŠ. ISTRAŽ. ZAGREB GOD. 20 (2011), BR. $1(111)$

STR. 167-187

RUČEVIĆ, S.: POVEZANOST.. father was related to a reduced risk for delinquency for boys, whereas the relationship was less apparent for girls. The findings also show that strong attachment to one parent is as effective in inhibiting delinquency as strong attachments to both parents. It was also found that strong attachment to the custodial parent in a single-parent home is as effective in controlling delinquency as strong attachments to both parents in a two-parent family.

Keywords: attachment, delinquent behavior, risk-taking behavior, social control theory

\section{Innigkeit des Kind-Eltern-Verhältnisses und Zusammenhänge zu delinquentem Verhalten bei Adoleszenten}

Silvija RUČEVIĆ

Philosophische Fakultät, Osijek

In dieser Arbeit soll die Innigkeit des Kind-Eltern-Verhältnisses an mehreren Dimensionen (Kommunikation, Vertrauen,

Enffremdung) ermittelt und hernach geprüft werden, ob es einen Zusammenhang zu verschiedenen Formen von Delinquenz- und Risikoverhalten unter Jugendlichen gibt. An der Untersuchung nahmen 226 Jungen und 480 Mädchen im Alter zwischen 13 und 19 Jahren teil. Konkret sollte ermittelt werden, ob (a) das Geschlecht die Auswirkungen des Kind-Eltern-Verhältnisses auf eventuelles Risiko- oder Delinquenzverhalten modifziert und ob (b) die Eltern bzw. ein Elternteil, zu dem besagtes inniges Verhältnis besteht, ebenfalls Auswirkungen auf bestimmte Formen von Risiko- oder Delinquenzverhalten haben können. Sowohl Delinquenz- und Risikoverhalten als auch die Innigkeit des Kind-Eltern-Verhältnisses wurden aufgrund von eigenen Einschätzungen der Befragten bestimmt. Die Ergebnisse zeigen, dass die Geschlechtszugehörigkeit ganz allgemein die Innigkeit des Kind-Eltern-Verhältnisses beeinflusst, ebenso delinquentes, nicht jedoch auch Risikoverhalten. Eine weitere Analyse ergab, dass das Delinquenzverhalten männlicher Jugendlicher bei gesteigerter Innigkeit des Kind-Eltern-Verhältnisses stärker zurückgeht als bei Mädchen. Des Weiteren wurde klar, dass bei Bestehen eines innigen Verhältnisses zu einem Elternteil Delinquenzverhalten ebenso inhibiert wird wie beim innigen Verhältnis zu beiden Elternteilen. Dieselbe Wirkung zeigt ein inniges Verhältnis zu einem allein erziehenden Elternteil, das Risiko- und Delinquenzverhalten dämmen kann und dem innigen Verhältnis zu beiden Elternteilen innerhalb einer intakten Familie ebenbürtig ist.

Schlüsselbegriffe: Innigkeit des Kind-Eltern-Verhältnisses, Delinquenzverhalten, Risikoverhalten, Theorie der Sozialkontrolle 